\title{
INDUCTIVE TEACHING AND LEARNING METHODS: DEFINITIONS, COMPARISONS, AND RESEARCH BASES ${ }^{*}$
}

\author{
Michael J. Prince \\ Bucknell University \\ Richard M. Felder \\ North Carolina State University
}

To state a theorem and then to show examples of it is literally to teach backwards. (E. Kim Nebeuts)

\begin{abstract}
Traditional engineering instruction is deductive, beginning with theories and progressing to applications of those theories. Alternative teaching approaches are more inductive. Topics are introduced by presenting specific observations, case studies or problems, and theories are taught or the students are helped to discover them only after the need to know them has been established. This study reviews several of the most commonly used inductive teaching methods, including inquiry learning, problem-based learning, project-based learning, case-based teaching, discovery learning, and just-in-time teaching. The paper defines each method, highlights commonalities and specific differences, and reviews research on the effectiveness of the methods. While the strength of the evidence varies from one method to another, inductive methods are consistently found to be at least equal to, and in general more effective than, traditional deductive methods for achieving a broad range of learning outcomes.
\end{abstract}

\section{INTRODUCTION}

\section{A. Two Approaches to Education}

Engineering and science are traditionally taught deductively. The instructor introduces a topic by lecturing on general principles, then uses the principles to derive mathematical models, shows illustrative applications of the models, gives students practice in similar derivations and applications in homework, and finally tests their ability to do the same sorts of things on exams. Little or no attention is initially paid to the question of why any of that is being done-what realworld phenomena can the models explain, what practical problems can they be used to solve, and why the students should care about any of it. The only motivation to learn that students get - if they get any at all - is suggestions that the material will be important later in the curriculum or in their careers.

A well-established precept of educational psychology is that people are most strongly motivated to learn things they clearly perceive a need to know [1]. Simply telling students that they will need certain knowledge and skills some day is not a particularly effective motivator. A preferable alternative is inductive teaching and learning. Instead of beginning with general principles and eventually getting to applications, the instruction begins with specifics - a set of observations or experimental data to interpret, a case study to analyze, or a complex real-world problem to solve. As the students attempt to analyze the data or scenario or solve the problem,

* J. Engr. Education, 95(2), 123-138 (2006). 
they generate a need for facts, rules, procedures, and guiding principles, at which point they are either presented with the needed information or helped to discover it for themselves.

Inductive teaching and learning is an umbrella term that encompasses a range of instructional methods, including inquiry learning, problem-based learning, project-based learning, case-based teaching, discovery learning, and just-in-time teaching. These methods have many features in common, besides the fact that they all qualify as inductive. They are all learnercentered (aka student-centered), meaning that they impose more responsibility on students for their own learning than the traditional lecture-based deductive approach does. They are all supported by research findings that students learn by fitting new information into existing cognitive structures and are unlikely to learn if the information has few apparent connections to what they already know and believe. They can all be characterized as constructivist methods, building on the widely accepted principle that students construct their own versions of reality rather than simply absorbing versions presented by their teachers. The methods almost always involve students discussing questions and solving problems in class (active learning), with much of the work in and out of class being done by students working in groups (collaborative or cooperative learning). The defining characteristics of the methods and features that most of them share are summarized in Table 1.

Table 1. Features of Common Inductive Instructional Methods

\begin{tabular}{|c|c|c|c|c|c|c|}
\hline $\begin{array}{l}\text { Method } \rightarrow \\
\text { Feature } \\
\downarrow\end{array}$ & 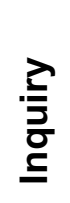 & 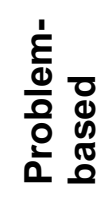 & 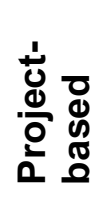 & 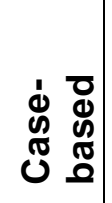 & 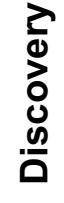 & 卡 \\
\hline Questions or problems provide context for learning & 1 & 2 & 2 & 2 & 2 & 2 \\
\hline $\begin{array}{l}\text { Complex, ill-structured, open-ended real-world } \\
\text { problems provide context for learning }\end{array}$ & 4 & 1 & 3 & 2 & 4 & 4 \\
\hline Major projects provide context for learning & 4 & 4 & 1 & 3 & 4 & 4 \\
\hline Case studies provide context for learning & 4 & 4 & 4 & 1 & 4 & 4 \\
\hline Students discover course content for themselves & 2 & 2 & 2 & 3 & 1 & 2 \\
\hline $\begin{array}{l}\text { Students complete \& submit conceptual exercises } \\
\text { electronically; instructor adjusts lessons according to } \\
\text { their responses }\end{array}$ & 4 & 4 & 4 & 4 & 4 & 1 \\
\hline Primarily self-directed learning & 4 & 3 & 3 & 3 & 2 & 4 \\
\hline Active learning & 2 & 2 & 2 & 2 & 2 & 2 \\
\hline Collaborative/cooperative (team-based) learning & 4 & 3 & 3 & 4 & 4 & 4 \\
\hline
\end{tabular}

1 - by definition, 2 - always, 3-usually, 4-possibly

There are also differences among the different inductive methods. The end product of a project-based assignment is typically a formal written and/or oral report, while the end product of a guided inquiry may simply be the answer to an interesting question, such as why an egg takes longer to boil at a ski resort than at the beach and how frost can form on a night when the temperature does not drop below freezing. Case-based instruction and problem-based learning involve extensive analyses of real or hypothetical scenarios while just-in-time teaching may simply call on students to answer questions about readings prior to hearing about the content of 
the readings in lectures. However, the similarities trump the differences, and when variations in how the methods are implemented are taken into account many of the differences disappear altogether.

Although we just claimed that inductive methods are essentially variations on a theme, they do not appear that way in the literature. Each method has its own history, research base, guidebooks, proponents, and detractors, and a great deal of confusion exists regarding what the methods are and how they are interrelated. Our objective in this paper is to summarize the definitions, foundations, similarities, and differences among inductive learning methods and to review the existing research evidence regarding their effectiveness.

Before we begin our review, we will attempt to clarify two points of confusion that commonly arise in discussions of inductive methods.

\section{- Is inductive learning really inductive?}

In practice, neither teaching nor learning is ever purely inductive or deductive. Like the scientific method, learning invariably involves movement in both directions, with the student using new observations to infer rules and theories (induction) and then testing the theories by using them to deduce consequences and applications that can be verified experimentally (deduction). Good teaching helps students learn to do both. When we speak of inductive methods, we therefore do not mean total avoidance of lecturing and complete reliance on selfdiscovery, but simply teaching in which induction precedes deduction. Except in the most extreme forms of discovery learning (which we do not advocate for undergraduate instruction), the instructor still has important roles to play in facilitating learning-guiding, encouraging, clarifying, mediating, and sometimes even lecturing. We agree with Bransford: "There are times, usually after people have first grappled with issues on their own, that 'teaching by telling' can work extremely well." [2, p. 11]

\section{- Are we talking about inductive learning or inductive teaching, or is there no difference?}

A common point of semantic confusion associated with inductive methods has to do with the distinction between teaching and learning. Thus, for example, one hears about problem-based learning but just-in-time teaching, and both inquiry learning and inquiry-based teaching are commonly encountered in the literature. There is of course a difference between learning (what students do) and teaching (what teachers do), but in this paper we will never examine one without explicitly or implicitly considering the other. The reader should therefore understand that when we refer to "inductive learning" or to an inductive instructional method with either teaching or learning in its name, we are talking about both strategies that an instructor might use (teaching) and experiences the students might subsequently undergo (learning).

\section{FOUNDATIONS OF INDUCTIVE TEACHING AND LEARNING}

\section{A. Constructivism}

According to the model of education that has dominated higher education for centuries (positivism), absolute knowledge ("objective reality") exists independently of human perception. The teacher's job is to transmit this knowledge to the students-lecturing being the natural method for doing so - and the students' job is to absorb it. An alternative model, constructivism, 
holds that whether or not there is an objective reality (different constructivist theories take opposing views on that issue), individuals actively construct and reconstruct their own reality in an effort to make sense of their experience. New information is filtered through mental structures (schemata) that incorporate the student's prior knowledge, beliefs, preconceptions and misconceptions, prejudices, and fears. If the new information is consistent with those structures it may be integrated into them, but if it is contradictory, it may be memorized for the exam but is unlikely to be truly incorporated into the individual's belief system - which is to say, it will not be learned.

Constructivism has its roots in the $18^{\text {th }}$-century philosophies of Immanuel Kant and Giambattista Vico, although some have traced it as far back as the $4^{\text {th }}-6^{\text {th }}$ century B.C. in the works of Lao Tzu, Buddha, and Heraclitus. The constructivist view of learning is reflected in the developmental theories of Piaget [3], Dewey [4], Bruner [5], and Vygotsky [6], among others. In cognitive constructivism, which originated primarily in the work of Piaget, an individual's reactions to experiences lead to (or fail to lead to) learning. In social constructivism, whose principal proponent is Vygotsky, language and interactions with others - family, peers, teachers - play a primary role in the construction of meaning from experience. Meaning is not simply constructed, it is co-constructed.

Proponents of constructivism (e.g., Biggs [7]) offer variations of the following principles for effective instruction:

- Instruction should begin with content and experiences likely to be familiar to the students, so they can make connections to their existing knowledge structures. New material should be presented in the context of its intended real-world applications and its relationship to other areas of knowledge, rather than being taught abstractly and out of context.

- Material should not be presented in a manner that requires students to alter their cognitive models abruptly and drastically. In Vygotsky's terminology, the students should not be forced outside their "zone of proximal development," the region between what they are capable of doing independently and what they have the potential to do under adult guidance or in collaboration with more capable peers [6]. They should also be directed to continually revisit critical concepts, improving their cognitive models with each visit. As Bruner [5] puts it, instruction should be "spirally organized."

- Instruction should require students to fill in gaps and extrapolate material presented by the instructor. The goal should be to wean the students away from dependence on instructors as primary sources of required information, helping them to become self-learners.

- Instruction should involve students working together in small groups. This attribute - which is considered desirable in all forms of constructivism and essential in social constructivismsupports the use of collaborative and cooperative learning.

The traditional lecture-based teaching approach is incompatible with all of these principles. If the constructivist model of learning is accepted - and compelling research evidence supports itthen to be effective instruction must set up experiences that induce students to construct knowledge for themselves, when necessary adjusting or rejecting their prior beliefs and misconceptions in light of the evidence provided by the experiences. This description might serve as a definition of inductive learning. 


\section{B. Cognition Research}

Bransford et al. [2] offer a comprehensive survey of neurological and psychological research that provides strong support for constructivism and inductive methods. Here are some of their findings:

- "All new learning involves transfer of information based on previous learning" [2, p. 53].

Traditional instruction in engineering and science frequently treats new courses and new topics within courses as self-contained bodies of knowledge, presenting theories and formulas with minimal grounding in students' prior knowledge and little or no grounding in their experience. Inductive instruction, on the other hand, presents new information in the context of situations, issues, and problems to which students can relate, so there is a much greater chance that the information can be linked to their existing cognitive structures.

Since learning is strongly influenced by prior knowledge, if new information is fully consistent with prior knowledge it may be learned with relative ease, but if it involves a contradiction several things may happen. If the contradiction is perceived and understood, it may initially cause confusion but the resolution of the contradiction can lead to elimination of misconceptions and greater understanding. However, if learners fail to understand the contradiction or if they can construct coherent (to them) representations of the new material based on existing misconceptions, deeper misunderstanding may follow [2, p. 70]. Traditional teaching generally does little to force students to identify and challenge their misconceptions, leading to the latter situation. The most effective implementations of inductive learning involve diagnostic teaching, with lessons being designed to "discover what students think in relation to the problems on hand, discussing their misconceptions sensitively, and giving them situations to go on thinking about which will enable them to readjust their ideas [2, p. 134]." The proper choice of focus questions and problems in inquiry-based, problem-based, and discovery learning methods can serve this function.

- Motivation to learn affects the amount of time students are willing to devote to learning. Learners are more motivated when they can see the usefulness of what they are learning and when they can use it to do something that has an impact on others [2, p. 61].

This finding supports techniques that use authentic (real-world, professionally relevant) situations and problems to provide contexts for learning the content and skills a course is intended to teach. Inductive methods such as problem-based learning and case-based teaching do this.

- The likelihood that knowledge and skills acquired in one course will transfer to real work settings is a function of the similarity of the two environments [2, p. 73].

School often emphasizes abstract reasoning while work focuses almost exclusively on contextualized reasoning. Organizing learning around authentic problems, projects, and cases helps to overcome these disparities and so improves the likelihood of subsequent transfer, in addition to increasing motivation to learn as noted in the previous item. Moreover, traditional schools differ from most work environments in that school heavily emphasizes individual work while most work involves extensive collaboration. Assigning teams to perform most required tasks (as most inductive methods do) thus further promotes transfer, provided that the students 
are helped to develop teamwork skills and the work is organized in a way that assures individual accountability for all of the learning that takes place [8-12].

- Helping students develop metacognition-knowledge of how they learn-improves the likelihood of their transferring information learned in one context to another one [2, p. 67].

Methods that train students in systematic problem-solving methods (generating and evaluating alternative solutions, periodically assessing progress toward the solution, extracting general principles from specific solutions, etc.) and call on them to make sense of new information, to raise questions when they cannot, and to regularly assess their own knowledge and skill levels promote the development of metacognitive skills. Most variants of problembased learning include such steps.

\section{Intellectual Development and Approaches to Learning}

Most college students undergo a developmental progression from a belief in the certainty of knowledge and the omniscience of authorities to an acknowledgment of the uncertainty and contextual nature of knowledge, acceptance of personal responsibility for determining truth, inclination and ability to gather supporting evidence for judgments, and openness to change if new evidence is forthcoming [13,14]. At the highest developmental level normally seen in college students (termed "contextual relativism" by Perry [13]), individuals display thinking patterns resembling those of expert scientists and engineers. A goal of science and engineering instruction should be to advance students to that level by the time they graduate.

In their courses, students may be inclined to approach learning in one of three ways [15]. Some take a surface approach, relying on rote memorization and mechanical formula substitution and making little or no effort to understand the material being taught. Others may adopt a deep approach, probing and questioning and exploring the limits of applicability of new material. Still others use a strategic approach, doing whatever is necessary to get the highest grade they can, taking a surface approach if that suffices and a deep approach when necessary. Another goal of instruction should be to induce students to adopt a deep approach to subjects that are important for their professional or personal development.

Felder \& Brent [16] observe that the characteristics of high levels of intellectual development and of a deep approach to learning are essentially the same. Both contextual relativism and a deep approach involve taking responsibility for one's own learning, questioning authorities rather than accepting their statements at face value, and attempting to understand new knowledge in the context of prior knowledge and experience. It is reasonable to assume that instructional conditions that induce students to adopt a deep approach should also promote intellectual growth.

Several conditions of instruction have been shown to promote a deep approach, including interest in and background knowledge of the subject, use of teaching methods that foster active and long-term engagement with learning tasks, and assessment that emphasizes conceptual understanding as opposed to recall or the application of routine procedural knowledge [17]. Well implemented inductive teaching methods serve all of these functions. Authentic problems and case studies can motivate students by helping to make the subject matter relevant, and they also tend to keep the students interested and actively engaged in their learning tasks. Having to 
analyze complex situations also promotes the students' adoption of a deep approach to learning, as rote memorization and simple algorithmic substitution are clearly inadequate strategies for dealing with such situations. Moreover, open-ended problems that do not have unique welldefined solutions pose serious challenges to students' low-level beliefs in the certainty of knowledge and the role of instructors as providers of knowledge. Such challenges serve as precursors to intellectual growth [14].

\section{Learning Cycle-Based Instruction}

Several well-known instructional models involve learning cycles, wherein students work through sequences of activities that involve complementary thinking and problem-solving approaches. In most of these cycles, the different activities are designed to appeal to different learning style preferences (concrete and abstract, active and reflective, etc.) [18]. When instructors teach around the cycle in this manner, all students are taught partly in a manner they prefer, which leads to an increased comfort level and willingness to learn, and partly in a less preferred manner, which provides practice and feedback in ways of thinking they might be inclined to avoid but which they will have to use to be fully effective professionals. Teaching around the best known of such cycles - that associated with Kolb's experiential learning model [19]involves (1) introducing a problem and providing motivation for solving it by relating it to students' interests and experience (the focal question is why?); (2) presenting pertinent facts, experimental observations, principles and theories, problem-solving methods, etc., and opportunities for the students to reflect on them (what?); (3) providing guided hands-on practice in the methods and types of thinking the lessons are intended to teach (how?); and (4) allowing and encouraging exploration of consequences and applications of the newly learned material (what if?).

A learning cycle developed at the Vanderbilt University Learning Technology Center is the STAR Legacy module [20], which consists of the following steps:

1. Students are presented with a challenge (problem, scenario, case, news event, or common misconception presenting the targeted content in a realistic context) that establishes a need to know the content and master the skills included in the learning objectives for the module.

2. The students then formulate their initial thoughts, reflecting on what they already know and think about the context of the challenge and generating ideas about how they might address the challenge.

3. Perspectives and resources are next provided. Perspectives are statements by experts that offer insights into various dimensions of the challenge without providing a direct solution to it, and resources may include lectures, reading materials, videos, simulations, homework problems, links to websites, and other materials relevant to the challenge.

4. Assessment activities are then carried out, in which the students apply what they know and identify what they still need to learn to address the challenge. The activities may include engaging in self-assessments and discussions, completing homework assignments, writing essays or reports, and taking on-line quizzes or exams. Multiple iterations between Steps 3 and 4 would normally be required to fully meet the challenge.

5. In the final wrap-up, an expert may present a model solution to the challenge, or the students may present a report and/or complete an examination showing that they have met the 
challenge and demonstrating their mastery of the knowledge and skills specified in the learning objectives.

The Star legacy module is a clear exemplar of an inductive approach to teaching and learning. Depending on the nature and scope of the challenge, instruction based on such a module would qualify as inquiry learning, project-based learning, or problem-based learning. Similarly, learning cycles based on learning styles that begin with the presentation of a realistic problem or challenge of some sort are inductive. Instruction based on learning cycles is consistent with accepted principles of cognitive science [2] and its effectiveness has been repeatedly demonstrated empirically [21].

In summary, inductive approaches to teaching and learning have much in their favor. They are supported by the best research on learning currently available, compatible with the currently most widely accepted theories of learning, and promotive of the problem-solving skills and attitudes to learning that most instructors would say they desire for their students. Following a brief section on assessment, we will examine the individual inductive methods - what they are, what they have in common and how they differ, and what is known about how well they succeed in achieving desired educational outcomes.

\section{ASSESSMENT AND EVALUATION OF INDUCTIVE METHODS}

Rigorous comparisons of inductive methods with traditional expository methods are not easy to design, for several reasons [22].

- There are many varieties of inductive approaches, each of which can be implemented in many ways - with greater or lesser instructor involvement, with or without formal facilitation of teamwork, with most of the work being done in or out of class, and so on. Two articles may claim to be studies of, say, problem-based learning, but they could involve dramatically different forms of instruction and may well produce different learning outcomes.

- Instructors may have varying degrees of experience and skill with whichever method they adopt. Two different instructors using the same method in the same class could get different results.

- Student populations also vary considerably, among other ways in distributions of gender and ethnicity, age, experience, motivation to learn, learning styles, and levels of intellectual development [21]. The same instructor could use the same method in two different classes and get different outcomes.

- The conclusions drawn from a study may depend strongly on the learning outcome investigated-acquisition of factual knowledge, development of a problem-solving or interpersonal skill, retention in a curriculum, self-confidence level, attitude, or any combination of these. An inductive method may be superior with respect to one outcome and inferior with respect to another. (We will shortly see an example of this phenomenon in the case of problem-based learning, which has frequently been found to lead to superior highlevel skills and attitudes but inferior short-term acquisition of factual knowledge.) Moreover, reliable and valid assessments of high-level skills such as critical or creative thinking or attributes such as lifelong learning skills are difficult to obtain, and two studies that use different assessment methods could arrive at different conclusions. 
- Finally, as Prince [22] points out, implementations of inductive approaches such as problembased learning normally involve active and collaborative learning methods, both of which are known to have positive effects on many learning outcomes. If an inductive method is found to have a positive effect, sorting out how much of it can be attributed to the method itself and how much to other methods imbedded in it can be a formidable challenge.

Considering these difficulties, it is not surprising that published studies report both positive and negative outcomes for inductive learning relative to conventional instruction. Given the difficulty (if not impossibility) of carrying out a clean and conclusive comparative study, the best we can do is to look at results from a number of studies with different instructors, implementations, learning outcomes, and student populations, to see if any robust generalizations can be inferred. The sections that follow summarize results of such meta-analyses.

\section{INQUIRY LEARNING}

\section{A. Definition and Applications}

Inquiry learning begins when students are presented with questions to be answered, problems to be solved, or a set of observations to be explained [23]. If the method is implemented effectively, the students should learn to "formulate good questions, identify and collect appropriate evidence, present results systematically, analyze and interpret results, formulate conclusions, and evaluate the worth and importance of those conclusions [24]." The same statements could also be made about problem-based learning, project-based learning, discovery learning, certain forms of casebased instruction, and student research, however, so that inquiry learning may be considered an umbrella category that encompasses several other inductive teaching methods. Lee makes this point, observing that inquiry is also consistent with interactive lecture, discussion, simulation, service learning, and independent study, and in fact "probably the only strategy that is not consistent with inquiry-guided learning is the exclusive use of traditional lecturing [24, p. 10]." In this paper we will use the term inquiry learning to refer to instruction that uses questions and problems to provide contexts for learning and does not fall into another more restrictive inductive learning category.

Besides overlapping with other inductive methods, inquiry learning encompasses a variety of techniques that differ from one another in significant ways. Staver and Bay [25] differentiate between structured inquiry (students are given a problem and an outline for how to solve it), guided inquiry (students must also figure out the solution method) and open inquiry (students must formulate the problem for themselves). Smith [26] makes a similar distinction between teacher inquiry, in which the teacher poses questions, and learner inquiry, in which questions are posed by the students. In process-oriented-guided-inquiry-learning (POGIL) (<http://www.pogil.org $>$ ), students work in small groups in a class or laboratory on instructional modules that present them with information or data, followed by leading questions designed to guide them toward formulation of their own conclusions. The instructor serves as facilitator, working with student groups if they need help and addressing class-wide problems when necessary. Some proponents of inquiry suggest using a relatively structured form of inquiry in the first year, gradually shifting toward more self-directed learning (including problem formulation) as the curriculum progresses, while others advocate moving immediately to selfdirection [24]. 
Inquiry-based methods have been used extensively in the sciences [27-32] and to a lesser extent in engineering [33,34]. Guided inquiry has been particularly widely used in chemistry curricula. The POGIL Web site (<http://www.pogil.org $>$ ) contains reports of implementations on several campuses, instructional materials for different branches of chemistry, and a video showing an implementation of the method in an introductory chemistry class (<http://www.pogil.org/resources/GI_video.php>).

Lee et al.[24] report on a series of inquiry-based courses in different disciplines at North Carolina State University that had four desired student outcomes in common: (a) improved critical thinking skills, (b) greater capacity for independent inquiry, (c) taking more responsibility for one's own learning, (d) intellectual growth (e.g., on the Perry scale of intellectual development). Following are several examples.

- Introductory chemistry and physics courses are conducted in a hands-on inquiry-based environment called SCALE-UP (Student-Centered Activities for Large Enrollment University Programs) [35]. Students read and take quizzes about assigned material before coming to class (a characteristic of Just-in-Time Teaching, another inductive technique to be discussed), and work in teams on activities designed to help them discover or investigate concepts for themselves.

- In an introductory first-year microbiology course, the students read articles, generate questions stimulated by the readings, identify underlying hypotheses and assumptions in the articles, discuss their findings in small groups, and submit both their individual work and group assignments. In honors sections of several third-year microbiology courses, the students do extensive analysis and interpretation of experimental data and case studies, with emphasis being placed on collecting and interpreting scientific data and testing hypotheses [36].

- In a first-year paper science and engineering course, the students complete an open-ended design project, and in another first-year course they spend most of their time working in teams on advanced problems at a level previously reserved for seniors, learning on their own a great deal of the material that would traditionally have been delivered in lectures [37].

- In an experimental College of Engineering program, instructors are given grants to develop innovative classroom applications of laptop computers with wireless Internet access, which are made available to all students in their courses. Courses in this program that made inquiry a significant component of their instruction included the second and third semesters of calculus, in which students used MAPLE ${ }^{\circledR}$ to explore solutions to real-world problems, and a course on JAVA programming, in which students worked in pairs at the computer during class to develop and implement programs and to clarify their conceptual understanding of programming principles [38].

\section{B. Evaluation}

Several published meta-analyses conclude that inquiry-based instruction is generally more effective than traditional instruction for achieving a variety of learning outcomes [26, 39]. Shymansky et al. [40] analyzed results from 81 experimental studies involving thousands of students and found that inquiry learning produced significant positive gains for academic achievement, student perceptions, process skills and analytic abilities. In a meta-analysis of 79 individual studies between 1965 and 1995 involving students from 7th grade through college, 
Smith [26] found that inquiry learning improved academic achievement (effect size $=0.33$ ), critical thinking skills (effect size $=0.77$ ) and laboratory skills (effect size $=0.14$ ). There was also a slight improvement in process skills (effect size $=0.05$ ), which was not statistically significant. In a meta-study of laboratory instruction conducted over roughly the same time period, Rubin [41] found that inquiry-based instruction was superior to traditional instruction for cognitive learning outcomes, which included conceptual and subject learning, reasoning ability, and creativity (effect size $=0.18$ ), as well as for non-cognitive outcomes, including manipulative skills and attitudes (effect size $=0.39$ ).

Colburn's review of the literature [42] concludes that inquiry-based methods are likely to be more effective than deductive methods in helping students gain understanding of concrete observable phenomena, and less so in helping them understand how scientists explain or model phenomena (e.g., via kinetic and molecular theories in chemistry and physics). He recommends focusing activities around questions that students can answer directly via investigation, which helps assure that the activities are oriented toward concrete concepts. He also advises emphasizing activities that use materials and situations familiar to students for which they have the necessary prerequisite skills and knowledge to succeed, but pose a sufficient level of challenge to help them develop better thinking skills.

\section{PROBLEM-BASED LEARNING}

\section{A. Definition and Applications}

Problem-based learning (PBL) begins when students are confronted with an open-ended, illstructured, authentic (real-world) problem and work in teams to identify learning needs and develop a viable solution, with instructors acting as facilitators rather than primary sources of information [43-50]. Class time may be devoted to (i) groups reporting out their progress on previous learning issues and listing their current learning issues and plans of work, (ii) minilectures giving information on issues being dealt with by all groups, clarifying common difficulties, and suggesting additional learning issues, and (iii) whole class discussion [50]. A well-designed problem guides students to use course content and methods, illustrates fundamental principles, concepts, and procedures, and perhaps induces the students to infer those things for themselves instead of getting them directly from the instructor; and engages the students in the types of reflection and activities that lead to higher-order learning. Problems may vary significantly in scope, from single-topic single-discipline problems that can be solved in a matter of days to multidisciplinary problems that may take an entire semester to solve. The formulation of problems is discussed by Weiss [47], Tan [48, Ch. 6], and several authors in the edited volume of Duch et al. [49].

PBL may be implemented in a variety of ways [50]. In the medical school model, students work in groups of 7-10 under the supervision of a faculty member or another designated tutor (e.g. a graduate student or advanced undergraduate). There is very little formal class time, if any. In the floating facilitator model, students work on problems in groups of 3-5 during class. The instructor moves from group to group during class, asking questions and probing for understanding. Different levels of external guidance may be provided by a faculty member or a designated tutor, or responsibility for the work may be taken by the groups themselves in what Woods [51] calls self-directed, interdependent, small group problem-based learning. Acar \& Newman [52] describe a module in which students in their final year of a systems engineering 
program served as tutors to first- and second-year students doing PBL-based project work. The experience was instructive for both the tutors and the tutees, with the former noting its helpfulness in interviews and as preparation for the workplace.

Modern problem-based learning originated in medical schools, principally those at Case Western Reserve University in the 1950s and McMaster University in the 1960s. It is now extensively practiced in medical education and other health-related disciplines including veterinary medicine and nursing [53], and in other fields including architecture, psychology, business and management, and engineering $[48,54]$. It has been used in a number of curricula at the University of Delaware and Samford University in the United States, McMaster University in Canada, the University of Maastricht in the Netherlands, Linköping University in Sweden, and the University of Newcastle in Australia; in chemical engineering at McMaster [51, 55], Bucknell University [56, 57] and the Universitat Rovira I Virgili in Spain [58] and civil engineering at Monash University in Australia [59-61]; and in an integrated physics, mathematics, and computer science course at the Instituto Tecnológico y de Estudios Superiores de Monterrey, Mexico [62]. PBL problems in chemistry \& physics (and many other fields) and guidance on how to use them are given in Duch et al. [49] and on Web sites maintained at the University of Delaware (<http://www.udel.edu/pbl/>) and Samford University (<http://www.samford.edu/pbl>), both of which provide links to many other resources. A 2003 issue of the International Journal of Engineering Education (Vol. 19, No. 5) is devoted entirely to PBL implementations at universities around the world.

Nelson [63] discusses using design projects as a basis for problem-based learning, observing that the stages of design-naming (identifying main issues in the problem), framing (establishing the limits of the problem), moving (taking an experimental action), and reflecting (evaluating and criticizing the move and the frame) provides an ideal framework for the PBL process. He cites examples in which he used PBL successfully to teach graduate courses in instructional design, software development, and project management. The previously described Star Legacy module developed at Vanderbilt University [20] provides another excellent framework for PBL.

\section{B. Evaluation}

Dochy et al. [64] published a meta-analysis of the effectiveness of problem-based learning. The authors identified 43 empirical studies of the effects of PBL on knowledge acquisition and development of problem-solving skills in college students. Only studies that utilized natural classroom instruction (as opposed to controlled laboratory studies) were included in the data base. The average effect size was calculated both in an unweighted form and with each effect size weighted by the inverse of the variance (which being proportional to $N$ gives greater weight to larger samples).

Seven of the studies analyzed found a positive effect of PBL on knowledge acquisition and 15 found a negative effect, with a weighted average effect size and 95\% confidence interval of $-0.223( \pm 0.058)$. When only true randomized tests are included, however, the negative effect of PBL on knowledge acquisition almost disappears, and when the assessment of knowledge is carried out some time after the instruction was given the effect of PBL is positive. The implication is that students may acquire more knowledge in the short term when instruction is conventional but students taught with PBL retain the knowledge they acquire for a longer period 
of time. For skill development, the results are unequivocal: 14 studies found a positive effect and none found a negative effect, and the weighted average effect size was $0.460( \pm 0.058)$. The positive effect of PBL on skill development holds regardless of whether the assessment is concurrent with the instruction or delayed.

Prince [22] examined several meta-analyses of problem-based learning, separately considering the effects of its constituent approaches: active learning (actively engaging students in the learning process in class, as opposed to merely presenting them with information), collaborative learning (students work on problems and projects collaboratively rather than doing everything individually), and cooperative learning (team-based learning in which certain criteria must be met, most notably individual accountability for all of the learning that is supposed to take place). He concluded that the strongest positive effects of PBL related to the student and faculty responses to the method and to a small but robust improvement in students' skill development. While a statistically significant effect was not found for improvement of academic achievement as measured by exams, there was evidence that PBL enhanced students' retention and ability to apply material.

Individual studies have found a robust positive effect of PBL on skill development $[1,65$, 66], understanding the interconnections among concepts [65], deep conceptual understanding [67], ability to apply appropriate metacognitive and reasoning strategies [68], teamwork skills [69], and even class attendance [70], but have not reached any firm conclusion about the effect on content knowledge. A longitudinal study of the effectiveness of the McMaster PBL program in chemical engineering demonstrated its superiority to traditional education in the development of key process skills [55]. PBL has also been shown to promote self-directed learning [71] and the adoption of a deep (meaning-oriented) approach to learning, as opposed to a superficial (memorization-based) approach [21, 46, 72].

Several papers discuss the possible tradeoff between knowledge acquisition and skill development, or alternatively, between breadth and depth of content coverage when PBL is used. de Graaf \& Kolmos [73] observe that students may be expected to reach a level of analytical comprehension through problem-based work that cannot be attained in conventionally-taught classes, but they might experience subject area gaps in doing so and so should be equipped to fill in such gaps when a need arises to do so. Perrenet et al. [74] make a similar point specifically related to engineering education. They observe that if PBL is implemented in a way that permits considerable self direction by the students, the learning that takes place may not necessarily attack and correct the misconceptions that hinder understanding of critical engineering concepts, which could in turn interfere with the students' ability to apply their learning to novel problems in a professional setting. They also note that unlike medicine, which has an encyclopedic structure, the knowledge structures of engineering and the sciences tend to be hierarchical. Engineering students engaged in self-guided PBL might easily overlook or bypass critical topics, which could interfere with future learning of important content, especially if the implementation of PBL is curriculum-wide rather than being limited to a few specific courses. Instructors should be aware of these potential pitfalls and design courses and problem sets so that all essential concepts are addressed.

Problem-based learning is not an easy instructional method to implement. It requires considerable subject expertise and flexibility on the part of instructors, who may be forced out of their areas of expertise when student teams set off in unpredictable and unfamiliar directions. 
PBL also makes students assume unaccustomed levels of responsibility for their own learning, and all of the project management problems and interpersonal conflicts that commonly occur when students are required to work in teams crop up in PBL. Many students are consequently hostile to PBL when they first encounter it, which can be intimidating to instructors who are unprepared for this reaction. Instructors - particularly relatively new ones - are therefore not advised to jump into full-scale problem-based learning until they familiarize themselves with proven facilitation techniques, and they are also advised to use scaffolding, providing a fairly high level of guidance to students who are new to PBL and gradually withdrawing it as the students gain more experience with the approach [75]. Tan [48, Ch. 4] provides an excellent guide to instructors on preparing students for PBL and helping them adjust to this instructional method, and good guidance is also provided by Duch et al. [49] and Woods [51].

The possibility of student resistance should not deter knowledgeable instructors from adopting the method. A number of studies offer evidence that most students who experience PBL eventually come to favor it over traditional methods [66, 67, 70, 76, 77].

\section{PROJECT-BASED LEARNING AND HYBRID (PROBLEM/PROJECT-BASED) APPROACHES}

\section{A. Definition and Applications}

Project-based learning begins with an assignment to carry out one or more tasks that lead to the production of a final product - a design, a model, a device or a computer simulation. The culmination of the project is normally a written and/or oral report summarizing the procedure used to produce the product and presenting the outcome. (Note: The acronym PBL is frequently used to denote project-based learning as well as problem-based learning. We will not do so in this paper to avoid adding to the confusion this labeling may cause.)

A tradeoff exists between instructors being fairly directive in choosing projects, which helps maintain a focus on course and curriculum objectives, and allowing students the autonomy to choose their own project formulations and strategies, which increases their motivation. de Graaf \& Kolmos [73] define three types of projects that differ in the degree of student autonomy:

- Task project: Student teams work on projects that have been defined by the instructor, using largely instructor-prescribed methods. This type of project provides minimal student motivation and skill development, and is part of traditional instruction in most engineering curricula.

- Discipline project: The instructor defines the subject area of the projects and specifies in general terms the approaches to be used (which normally involve methods common in the discipline of the subject area), but the students identify the specific project and design the particular approach they will take to complete it.

- Problem project: The students have nearly complete autonomy to choose their project and their approach to it.

de Graaf and Kolmos [73] note that a common difficulty faced by students in a projectbased environment is transferring methods and skills acquired in one project to another project in a different subject or discipline. Instructors should include such transference in their course 
objectives and should guide students to see connections between their current project and what they have learned previously, gradually withdrawing this support as the students become more adept at seeing the connections themselves. The instructors should also prepare students to fill in gaps in content knowledge when a need arises, taking into account the fact that such gaps may be more likely to arise in project-based learning than in conventional lecture-based instruction.

Project-based learning at the individual course level is familiar in engineering education, having been used almost universally in capstone design and laboratory courses and with growing frequency in first-year engineering courses and courses that engage students in consulting projects [78-80]. A few schools have made project-based learning the focus of many or most of their engineering courses, including the Universities of Aalborg and Roskilde in Denmark; Bremen, TU Berlin, Dortmund, and Oldenburg in Germany, Delft and Wageningen in the Netherlands [81], Monash University and Central Queensland University in Australia [82], and Olin College in the United States [83].

Project-based learning is similar to problem-based learning in several respects. Both normally involve teams of students in open-ended assignments that resemble challenges the students are likely to encounter as professionals, and both call for the students to formulate solution strategies and to continually re-evaluate their approach in response to outcomes of their efforts. There are differences in the two approaches as they have traditionally been implemented, however. A project typically has a broader scope and may encompass several problems. In addition, in project-based learning the end product is the central focus of the assignment and the completion of the project requires primarily application of previously acquired knowledge, while solving a problem requires the acquisition of new knowledge and the solution may be less important than the knowledge gained in obtaining it. In other words, the emphasis in projectbased learning is on applying or integrating knowledge while that in problem-based learning is on acquiring it.

In practice, however, the distinction between the two methods is not necessarily that clean, and programs have recently adopted approaches that include features of both of them. The University of Aalborg has the oldest and best known project-based engineering curriculum in the world, which began with the formation of the university in 1974. Project work accounts for roughly $50 \%$ of the curriculum, with task and problem projects dominating the first year of instruction, task and discipline projects dominating the second and third years, and problem projects dominating the fourth and fifth years [73]. The current approach at Aalborg is a hybrid of problem-based and project-based learning, with the projects being more about acquiring knowledge than applying it [84]. The main goal in the first year is to give students a general competence in project work and an awareness of general problem solving methods, while in the rest of the curriculum the focus shifts to more specific technical and scientific learning objectives, with the project work being mainly a mechanism for achieving those goals.

Aalborg has recently adapted its project-based approach to distance education offerings, with virtual groups meeting once or twice a week using Internet chat facilities [85]. Many of the positive features of project work have been observed in this format as well, although the authors note that the experience seems to accentuate the differences between strong and weak students, with the latter being more likely to become demotivated and to make less progress in the distance environment than they do in a conventional classroom environment. 
Another institutional implementation of problem/project-based learning was initiated in 2000 by the engineering school of the University of Louvain in Belgium, with both week-long problems and semester-long projects being routinely assigned to student teams in the first two years of the engineering curriculum [86]. The evaluation of this program summarized in the next section provides some of the best available evidence for the effectiveness of the hybrid approach.

\section{B. Evaluation}

Thomas [87] carried out an extensive review of research on project-based learning done primarily at the precollege level, considering only projects that (a) were central to the course, (b) focused on central concepts and principles of the discipline, (c) required acquisition of some new knowledge rather than being straightforward applications of existing knowledge, (d) were student-driven to some degree (as opposed to being "cookbook" exercises), and (e) were authentic, containing as many elements as possible of the type of environment the students are likely to encounter as professionals. The findings resemble those found for problem-based learning: comparable or somewhat better performance in project-based environments on tests of content knowledge, and significantly better performance on assessments of conceptual understanding and ability to solve problems that require it, metacognitive skills, and attitudes to learning. Thomas also cites studies suggesting that project-based learning may effectively reach students whose learning styles are poorly suited to a traditional lecture-based classroom environment.

More recently, Mills and Treagust [82] reviewed published evaluations of project-based learning programs in engineering and concluded that the findings are similar to those for problem-based learning in medicine. Relative to traditionally-taught students, students who participate in project-based learning are more motivated, demonstrate better communication and teamwork skills, and have a better understanding of issues of professional practice and how to apply their learning to realistic problems; however, they may have a less complete mastery of engineering fundamentals, and some of them may be unhappy over the time and effort required by projects and the interpersonal conflicts they experience in team work, particularly with teammates who fail to pull their weight. In addition, if the project work is done entirely in groups, the students may be less well equipped to work independently.

The hybrid (problem/project-based) curriculum at the University of Louvain was assessed by a multidisciplinary team of engineers and educators, who compared three cohorts of students who passed through the new curriculum with two cohorts from the final years of the old (traditional) curriculum [86]. The assessment measures included pretests and posttests of students' basic knowledge, understanding of concepts, and ability to apply them; students' selfefficacy, intrinsic vs. extrinsic goal orientation, satisfaction with the curriculum, learning and self-regulating strategies, and attitudes toward group work; and instructors' teaching practices, satisfaction with teaching, and perceptions of the impact of the PBL curriculum on the instructional environment. The student tests and questionnaire responses were blind-rated after the fourth year of the study, so that the raters did not know whether the subjects had gone through the old or the new curriculum.

The results of the Louvain study are dramatic. Of 79 between-group comparisons of knowledge, conceptual understanding, and application, 23 favored the new curriculum, one favored the old one, and the remainder showed no significant differences. Relative to students in 
the old curriculum, students in the new one felt that they received more support from their instructors, saw more connections between theory and practice, were more inclined to use autonomous learning strategies (search for information, seek help when needed, verify completed work), and were less reliant on rote memorization. The superior outcomes for the PBL-taught students could be attributed in part to their perception of greater support from their instructors, a factor known to have a positive impact on both performance and attitudes. They also felt that they had to work more and harder than students taught traditionally, and they had problems with being tested individually after doing most of their work in groups (a common complaint of students working in a heavily collaborative learning environment). Teachers in the study saw a positive impact of the PBL curriculum on student competencies in teamwork, modeling, transfer of knowledge, and analysis; the quality of student-teacher interactions and teacher-teacher interactions; their satisfaction with and pleasure in teaching; and their engagement in teaching and willingness to change their teaching practices. The last two outcomes were particularly strong among teachers who perceived their administration to be supportive of teaching (encouraging discussion of teaching, valuing teaching improvement, and offering training and collegial support). This result has important implications for the critical role of administrators in attempts to reform education.

\section{CASE-BASED TEACHING}

\section{A. Definition and Applications}

In case-based teaching, students analyze case studies of historical or hypothetical situations that involve solving problems and/or making decisions. Kardos \& Smith [88] defined a case in the context of engineering education as "an account of an engineering activity, event or problem containing some of the background and complexities actually encountered by an engineer." The same definition (with the appropriate substitution being made for "engineering") applies to law, medicine, management, teacher education, or any of the other fields that have made extensive use of cases for professional training.

Cases in all fields typically involve one or more challenges of various types, such as diagnosing technical problems and formulating solution strategies, making business management decisions taking into account technical, economic, and possibly social and psychological considerations, and confronting ethical dilemmas. The cases should be authentic - representative of situations likely to be encountered in professional practice - and may be drawn from stories in newspapers or magazines or built from interviews with individuals involved in the situations in question. A case might include descriptions of what happened and what led up to it, the problems and challenges, the resources and constraints under which solutions could be sought, the decisions that were made, the actions that were taken, and the outcomes. The idea is that in analyzing complex authentic cases, the students become aware of the kinds of situations and dilemmas they might have to face as professionals, gain both theoretical and practical understanding of their subjects, develop critical reasoning skills, explore their existing preconceptions, beliefs, and patterns of thinking, and make necessary modifications in those preconceptions, beliefs, and patterns to accommodate the realities of the cases [89]. These attributes of case-based teaching - particularly those related to making students aware of their preconceptions and beliefs - clearly fit comfortably in the framework of constructivism. 
Whether or not case-based instruction qualifies as inductive (and, one might suspect, whether and how well it succeeds) depends on how it is implemented. In one variant (which Lynn [90] terms a "research case"), the case is a complete narrative of a problematic situation, how people dealt with it, and what the outcomes were. Students may be called on to study the case ahead of time and be prepared to discuss it in class, but the same may be said of any traditional lecture-based approach that incorporates Socratic questioning. Lynn observes that research cases can be useful for illustrating appropriate, typical, or exemplary decision making but not for teaching critical thinking and decision-making skills, since in those cases the thinking has already been done, the decisions made, and the outcomes determined and given to the students. Instruction based on the use of such cases cannot be considered inductive.

Forms of case-based instruction that are inductive use what Lynn calls "teaching cases," in which the circumstances of the case are described but the decisions made by the protagonists are withheld so that the students can do their own analysis and decision-making. Analyses of teaching cases involve several steps [91]: (1) Review of the case content, (2) statement of the problem, (3) collection of relevant information, (4) development of alternatives, (5) evaluation of alternatives, (6) selection of a course of action, and (7) evaluation of solutions, and possibly review of actual case outcomes. The similarities of this method to problem-based learning are evident; however, unlike the problems generally used in PBL, cases tend to be relatively wellstructured, rich contextual details are provided, and students are called on to apply material that is already somewhat familiar, whereas PBL tends to use poorly structured problems to drive the acquisition of new content knowledge [92].

The use of cases for teaching probably goes back to the Harvard Law School in about 1870. The method was subsequently adopted by the Harvard Business School after World War I, and is now used routinely in schools of law, medicine, public administration and business management [90]. Cases are also used with increasing frequency in science education [93] and engineering education [94, 95]. Libraries of cases in science and engineering and resources for teachers wishing to use them have been compiled by the National Center for Case Study Teaching in Science [Web site], the Penn State Center for Teaching and Learning with Technology [Web site], and the Center for Case Studies in Engineering $[<h t t p: / / w w w . c i v e n g . c a r l e t o n . c a / E C L />$ ]. Most of the cases in the latter database are decades old and might therefore involve obsolete technology, but they should still be useful vehicles for promoting the types of critical thinking and problem-solving skills that are as vital today as they were when the cases were developed. Engineering case studies are also regularly published in the Journal of STEM Education (<http://www.jstem.org $>$ ).

\section{B. Evaluation}

Case-based teaching has strong proponents among practitioners; however, there is relatively little solid empirical support for it, a fact noted by several authors [89, 96, 97]. Lundeberg et al. [89] report that the use of case studies enhanced students' ability to recognize multiple perspectives (a finding that is further supported by Adams [98]), and they also note that the use of cases developed students' ability to identify relevant issues. Levin [99] found that cases improved students' reasoning and problem-solving skills, and Gabel [100] claims that they increased the use of higher-order thinking on Bloom's taxonomy. Fasko [97] found that most studies he examined showed little or no difference in knowledge acquisition between case studies, discussion, and lecture-based methods, but both cases and discussions were better than lectures 
for retention and application of material as well as problem-solving skills. Katsikitis et al. [101] compared case studies to PBL and found no significant difference between the two methods related to performance or knowledge acquisition.

\section{DISCOVERY LEARNING}

\section{A. Definition}

Discovery learning is an inquiry-based approach in which students are given a question to answer, a problem to solve, or a set of observations to explain, and then work in a largely selfdirected manner to complete their assigned tasks and draw appropriate inferences from the outcomes, "discovering" the desired factual and conceptual knowledge in the process [5]. In the purest form of this method, teachers set the problems and provide feedback on the students' efforts but do not direct or guide those efforts. This method is rarely used in higher education, among other reasons because instructors who hear about it fear - probably with good cause - that they would only be able to cover a small fraction of their prescribed content if students were required to discover everything for themselves. The only way to counter this fear would be to present solid evidence that discovery learning produces improved learning outcomes without requiring a major sacrifice of content, and as we will see in the next section, such evidence does not exist. What instructors are more likely to do is apply a variant of discovery learning (sometimes called "guided discovery") that involves the instructor providing some guidance throughout the learning process [102]. Once this is done, the distinctions between discovery and guided inquiry or problem-based learning tend to disappear.

\section{B. Evaluation}

Leonard [103] studied the use of guided inquiry and discovery learning in science laboratory courses, and found no statistically significant differences in student scores on tests and lab reports. Some studies suggest that discovery learning can enhance students' retention of material and others reach the opposite conclusion [104-108]. The studies that show a positive effect also suggest that retention is improved only when the learning task is based on previously understood principles. Singer and Pease [109] compared the effectiveness of guided inquiry and discovery learning on the acquisition, transfer and retention of motor skills. They concluded that for learning new tasks, guided inquiry was more efficient, and for transferring learned skills to tasks of similar or greater difficulty there was no difference.

\section{JUST-IN-TIME TEACHING}

\section{A. Definition and Applications}

Just-in-time teaching (JiTT) combines Web-based technology with active learning methods in the classroom [110-113]. Students individually complete Web-based assignments a few hours before class in which they answer questions, and the instructor reads through their answers before class and adjusts the lessons accordingly ("just in time"). This process is repeated several times a week. The use of questions to drive learning makes the method inductive. The technique was developed jointly by physics faculty at IUPUI, the U.S. Air Force Academy, and Davidson College. It can be combined with almost any in-class active learning approach. 
The preliminary Web-based exercises (termed "Warmups" at IUPUI and Davidson and "Preflights" at the Air Force Academy) normally require the student to preview the textbook material. The exercises are conceptual in nature and are designed to help students confront misconceptions they may have about the course material. They serve the functions of encouraging students to prepare for class regularly, helping teachers to identify students' difficulties in time to adjust their lesson plans, and setting the stage for active engagement in the classroom. They are individualized to minimize plagiarism and graded using an automated online system, although the authors stress the importance of instructors reading a representative selection of responses to monitor the students' qualitative understanding of the material. The students may submit solutions any number of times with no penalty until they get them correct.

JiTT resources also include enrichment materials of several types [110]:

- course-related news stories that demonstrate the real-world relevance of the course material, historical anecdotes, and descriptions of familiar phenomena or devices that illustrate course concepts;

- on-line homework, extra-credit assignments that often deal with the enrichment materials, and "puzzles," additional conceptual questions that force the students to think about the material at a deeper level than the straightforward preparatory assignments;

- various computer-based mechanisms for communication between students and the instructor and among students, including an electronic suggestion box that instructors monitor regularly, a course bulletin board that students may use to communicate among themselves (e.g. to set up study sessions or team meetings, or to raise and answer questions), archives of previous materials, and a "credit check" in which they can monitor their assignment grades and see how they are doing with respect to the class as a whole.

Novak et al. [112], the physicists who developed JiTT, cast many of their Web-based materials in the form of Java applets that they call physlets. The students are presented with a problem that presents a set of observations or experimental data in a visual manner, and they have to analyze it qualitatively before they are allowed to do any mathematical analysis, figuring out what they know and what they need to find out and then planning a solution strategy. The connection to inquiry learning and problem-based learning is clear.

JITT classes are a combination of interactive lectures, in which the instructor does a fair amount of mini-lecturing between activities; collaborative recitations, which are not necessarily preceded by preparatory Web-based exercises, and laboratories. In the lectures, the instructor might begin by summarizing student responses to the preparatory exercises and then discussing common errors. The end of the lecture might involve a similar discussion of a puzzle. The collaborative recitations are likely to begin with a review of the homework, and then teams of students work on new problems. Faculty members circulate, help teams that need help, and if a common problem emerges, provide some instruction on how to address it. Lectures and recitations may be held separately or they may be integrated with each other and with laboratories. Paper homework is assigned in addition to the preparatory web-based exercises. 


\section{B. Evaluation}

Novak et al. [112] assess JiTT for its impact on cognitive outcomes, student attrition and student attitudes in physics. Student learning was assessed using the Force Concept Inventory, which showed normalized student gains between $35 \%$ and $40 \%$. This gain is similar to that found for other interactive-engagement teaching methods [114] and is significantly better than the average normalized gains found in traditionally-taught physics courses. The authors also report that JiTT reduced student attrition by $40 \%$ compared to previous offerings taught traditionally and that student responses to JiTT have been overwhelmingly positive.

\section{GETTING STARTED WITH INDUCTIVE TEACHING AND LEARNING}

Once instructors are persuaded that inductive teaching methods are worth attempting, they face the question of which method to use. The answer, like the answer to all real questions, begins with "it depends": specifically, it depends on the instructor's learning objectives, the instructor's and the students' prior experience with learner-centered teaching methods, the instructor's confidence in his or her content knowledge and teaching skill, and the availability of local expertise and support for each of the various methods.

Before teaching a topic or series of lessons using any inductive method, the instructor should write learning objectives that define what the student should be able to do (explain, calculate, derive, design, model, critique,...) when the instruction has been concluded. The objectives should guide the choice of focus problems, learning activities, and assessment methods. Mager [115] and Gronlund [116] provide guidance on how to write effective learning objectives, and Felder and Brent [117] discuss writing objectives to address Outcomes 3a-3k of the ABET Engineering Criteria.

Once learning objectives have been defined, a suitable inductive instructional method may be identified. We propose the following guidelines for making the choice:

- Inquiry learning. Inquiry is the simplest of the inductive approaches and might be the best one for inexperienced or previously traditional instructors to begin with. It requires designing instruction so that as much learning as possible takes place in the context of answering questions and solving problems. As the students gain more experience with this approach, the instructor may increase the scope and difficulty of the focus questions, use more open-ended and ill-structured problems and simultaneously decrease the amount of explicit guidance provided.

- Problem-based learning. Problem-based learning is the most complex and difficult to implement of the methods reviewed in this paper. It calls for a complex, open-ended, authentic problem whose solution requires knowledge and skills specified in the learning objectives. Such problems take time to create. PBL also requires considerable teaching skill for instructors to deal with unfamiliar technical questions and problems, student resistance and possibly hostility toward PBL, and the array of interpersonal problems that frequently arise when students work in teams. Full-fledged PBL is therefore best undertaken by experienced instructors with solid expertise in the subject matter of the course and two or more semesters of experience with cooperative learning in a more conventional instructional environment. Smith et al. [118] offer suggestions for implementing cooperative learning, and Felder and Brent [8, 119] and Oakley et al. [10] suggest strategies for overcoming student 
resistance to learner-centered instructional methods and helping student groups become effective teams. Despite the challenges, PBL is a natural environment in which to develop students' professional skills such as problem-solving, team work and self-directed or lifelong learning, and it provides an excellent format to integrate material from across the curriculum. Instructors wishing to focus specifically on these learning outcomes should consider adopting PBL.

- Project-based learning and hybrid problem/project-based approaches. Project-based learning is well suited to the capstone design course in engineering and to laboratory courses that are more than collections of cookbook experiments, and it may also be used in other courses that deal with process or product design and development. Like the focus problems in problem-based learning, projects should be authentic and should address the instructor's learning objectives; moreover, if students work in teams, the instructor should observe the principles of cooperative learning including holding all team members individually accountable for the entire project content and facilitating their acquisition of teamwork skills $[8,10,118,119]$. As instructors and students gain experience with project-based learning, the projects may be made more open-ended with less guidance being provided on how to complete them. In other words, they may be increasingly structured as problem-based learning exercises.

- Case-based teaching. Cases are effectively used when learning objectives include decisionmaking in complex authentic situations. With appropriate selection, case-based teaching can also provide an excellent environment in which to address specific ABET mandated outcomes such acquiring an understanding professional and ethical responsibility, knowledge of contemporary issues or the ability to understand engineering solutions in a global and societal context. Scenarios suitable for cases might involve diagnosing technical problems and formulating solution strategies, making business management decisions taking into account technical, economic, and possibly social and psychological considerations, and confronting ethical dilemmas. Formulating good cases can be a difficult and time-consuming task; before trying to do it, instructors should first check the libraries of cases in science and engineering cited in Section VII to see if an existing case addresses their learning objectives.

- Just-in-time teaching. JiTT is a natural method to use when (1) it is important to the instructor that the students keep up with readings and assignments on a day-by-day basis, and (2) course management software is available and convenient to use for administering on-line assignments and assessing the students' responses. Instructors who plan to use the method should have solid expertise in the course content and the flexibility needed to modify their lectures on short notice after examining students' responses to the preliminary exercises. Also, a significant expenditure of time and effort is sure to be required if the preliminary Web-based exercises and Java applets must all be developed from scratch. Before undertaking this task, instructors should see if materials can be obtained from colleagues at their institution or elsewhere who have used JiTT for the same course.

We do not recommend using the pure form of discovery learning - in which students work with little or no guidance from instructors - in undergraduate engineering curricula.

Once the decision about adoption of a method is made, the instructor should refer to texts, articles, and Web-based resources on the chosen method and take full advantage of experienced colleagues and teaching center consultants who can offer tips on implementing it and dealing with problems that arise with its use. 


\section{SUMMARY}

The traditional approach to teaching science and engineering is deductive, beginning with the presentation of basic principles in lectures and proceeding to the repetition and application of the lecture content by the students. The teaching methods discussed in this paper-inquiry learning, problem-based learning, project-based learning, case-based teaching, discovery learning, and just-in-time teaching - instead proceed inductively, beginning with observations to be interpreted, questions to be answered, problems to be solved, or case studies to be analyzed. The content knowledge, methods, and skills that the course is designed to teach are acquired by the students, with varying degrees of instructor guidance, in the context of those exercises. If and when instructors present information, they do so only once the need for that information to complete the exercises has been established.

While the quality of research data supporting the different inductive methods is variable, the collective evidence favoring the inductive approach over traditional deductive pedagogy is conclusive. Induction is supported by widely accepted educational theories such as cognitive and social constructivism, by brain research, and by empirical studies of teaching and learning. Inductive methods promote students' adoption of a deep (meaning-oriented) approach to learning, as opposed to a surface (memorization-intensive) approach. They also promote intellectual development, challenging the dualistic type of thinking that characterizes many entering college students (which holds that all knowledge is certain, professors have it, and the task of students is to absorb and repeat it) and helping the students acquire the critical thinking and self-directed learning skills that characterize expert scientists and engineers.

This is not to say, however, that simply adopting an inductive method will automatically lead to better learning and more satisfied students. As with any form of instruction, inductive teaching can be done well or poorly, and the outcomes that result from it are only as good as the skill and care with which it is implemented. Many students are resistant to any type of instruction that makes them more responsible for their own learning, and if the appropriate amount of guidance and support is not provided when inductive methods are used, the resistance can escalate to hostility, inferior learning outcomes, poor evaluations, and a resolution by the instructor never to try anything like that again.

Instructors who set out to implement an inductive method should therefore first familiarize themselves with best practices such as providing adequate scaffolding-extensive support and guidance when students are first introduced to the method, followed by gradual withdrawal of the support as the students gain more experience and confidence in its use. Instructors should also anticipate some student resistance to inductive learning and should be aware of effective strategies for defusing it, many of which are outlined by Felder and Brent [8, $16,119]$. If these precautions are taken, both the students and the instructor should soon start seeing the positive outcomes promised by the research.

\section{ACKNOWLEDGMENTS}

The authors are grateful to Rebecca Brent, Valri Hammonds, Anette Kolmos, and Virginia Lee for reading a preliminary draft of the paper and offering valuable comments and suggestions for its improvement. 


\section{REFERENCES}

1. Albanese, M.A., and Mitchell, S. "Problem-Based Learning: A Review of Literature on its Outcomes and Implementation Issues," Academic Medicine, Vol. 68, 1993, pp. 52-81.

2. Bransford, J.D., Brown, A.L., and Cocking, R.R., eds., How People Learn: Brain, Mind, Experience, and School, Washington, D.C.: National Academy Press, 2000. Online at <http://www.nap.edu/ books $/ 0309070368 / \mathrm{html} />$.

3. Piaget, J., The Psychology of the Child, New York: Basic Books, 1972.

4. Dewey, J., How We Think, Mineola, New York: Dover, 1997 (reproduction of the 1910 work published by D.C. Heath).

5. Bruner, J.S., "The Act of Discovery," Harvard Educational Review, Vol. 31, No. 1, 1961.

6. Vygotsky, L.S., Mind in Society, Cambridge, MA: Harvard University Press, 1978.

7. Biggs, J., "Enhancing Teaching through Constructive Alignment," Higher Education, Vol. 32, 1996, pp. $1-18$.

8. Felder, R.M. and Brent, R. "Effective Strategies for Cooperative Learning," J. Cooperation and Collaboration in College Teaching, Vol. 10, No. 2, 69-75 (2001), <http://www.ncsu.edu/felderpublic/Papers/CLStrategies(JCCCT).pdf>.

9. Johnson, D.W., Johnson, R.T., and Stanne, M.E., Cooperative Learning Methods: A Meta-Analysis, University of Minnesota, Minneapolis: Cooperative Learning Center, 2000, <http://www.cooperation.org/pages/ cl-methods.html>.

10. Oakley, B., Felder, R.M., Brent, R., and Elhajj, I., "Turning Student Groups into Effective Teams," J. Student Centered Learning, Vol. 2, No. 1, 2004, pp. 9-34, <http://www.ncsu.edu/felderpublic/Papers/Oakley-paper(JSCL).pdfs.

11. Springer, L., Stanne, M.E., and Donovan, S., Effects of Small-Group Learning on Undergraduates in Science, Mathematics, Engineering, and Technology: A Meta-Analysis, Madison, WI: National Institute for Science Education, 1997, <http://www.wcer.wisc.edu/nise/CL1/CL/resource/R2.htm>.

12. Terenzini, P.T., Cabrera, A.F., Colbeck, C.L., Parente, J.M., and Bjorklund, S.A., "Collaborative Learning vs. Lecture/Discussion: Students' Reported Learning Gains,” J. Engr. Education, Vol. 90, No. 1, 2001, pp. 123-130.

13. Perry, W.G., Forms of Intellectual and Ethical Development in the College Years: A Scheme, San Francisco, Cal.: Jossey-Bass, 1988. (An updated reprint of the original 1970 volume.)

14. Felder, R.M., and Brent, R., "The Intellectual Development of Science and Engineering Students. 1. Models and Challenges," J. Engr. Education, Vol. 93, No. 4, 2004, pp. 69-277, $<$ http://www.ncsu.edu/felder-public/Papers/IntDev-I.pdfs.

15. Marton, F. and Säljö, R., "Approaches to Learning," in F. Marton, D. Hounsell, and N. Entwistle, eds., The Experience of Learning, $2^{\text {nd }}$ ed., Edinburgh: Scottish Academic Press, 1997.

16. Felder, R.M., and Brent, R., "The Intellectual Development of Science and Engineering Students. 2. Teaching to Promote Growth," J. Engr. Education, Vol. 93, No. 4, 2004, pp. 279-291, $<$ http://www.ncsu.edu/felder-public/Papers/IntDev-II.pdfs.

17. Ramsden, P., Learning to Teach in Higher Education, $2^{\text {nd }}$ ed., London: Taylor and Francis, Inc., 2003.

18. Felder, R.M., "Matters of Style," ASEE Prism, Vol. 6, No. 4, 1996, pp. 18-23, $<$ http://www.ncsu.edu/felder-public/Papers/LS-Prism.htm>.

19. Kolb, D.A., Experiential Learning: Experience as the Source of Learning and Development, Englewood Cliffs, NJ: Prentice-Hall, 1984.

20. "Star Legacy Modules," Iris Center for Faculty Enhancement, Vanderbilt University, $<$ http://iris.peabody.vanderbilt.edu/slm.html . 
21. Felder, R.M., and Brent, R., "Understanding Student Differences," J. Engr. Education, Vol. 94, No. 1, 2005, pp. 57-72, < http://www.ncsu.edu/felder-public/Papers/Understanding_Differences.pdfs.

22. Prince, M., "Does Active Learning Work? A Review of the Research," J. Engr. Education, Vol. 93, No. 3, 2004, pp. 223-231.

23. Bateman, W., Open to Question: The Art of Teaching and Learning by Inquiry, San Francisco: Jossey-Bass, 1990.

24. Lee, V.S., ed., Teaching and Learning through Inquiry, Sterling, VA: Stylus Publishing, 2004.

25. Staver, J.R., and Bay, M., "Analysis of the Project Synthesis Goal Cluster Orientation and Inquiry Emphasis of Elementary Science Textbooks," J. Research in Science Teaching, Vol. 24, 1987, pp. 629-643.

26. Smith, D., A Meta-Analysis of Student Outcomes Attributable to the Teaching of Science as Inquiry as Compared to Traditional Methodology, Ph.D. dissertation, Temple University, Department of Education, 1996.

27. McDermott, L.C., Physics by Inquiry, Physics Education Group, Physics Dept., University of Washington, Seattle, WA, 1995.

28. Thacker, B., Eunsook, K., Trefz, K., and Lea, S., "Comparing Problem Solving Performance of Physics Students in Inquiry-Based and Traditional Introductory Physics Courses," Am. J. of Physics, Vol. 62, No. 7, 1994, p. 627.

29. Tretter, T., and Jones, M., "Relationships Between Inquiry-Based Teaching and Physical Science Standardized Test Scores," School Sci. Math., Vol. 103, No. 7, 2003, p. 345.

30. Londraville, R., Niewiarowski, P., Laipply, R., and Owens, K., "Inquiry-Based Laboratories for Introductory Biology," Int. and Comp. Bio., Vol. 42, No. 6, 2002, p. 1267.

31. Heflich, D., Dixon, J., and Davis, K., "Taking It to the Field: The Authentic Integration of Mathematics and Technology in Inquiry-Based Science Instruction," J. Comp. Math. Sci. Teach., Vol. 20, No. 1, 2001, p. 99.

32. Schlenker, R., and Schlenker, K., "Integrating Science, Mathematics, and Sociology in an InquiryBased Study of Changing Population Density," Sci. Act., Vol. 36, No. 4, 2000, p. 16.

33. Buch, N., and Wolff, T., "Classroom Teaching through Inquiry," J. Prof. Issues Eng. Ed. Prac., Vol. 126, No. 3, 2000, p. 105.

34. Stahovich, T.F., and Bal, H., "An Inductive Approach to Learning and Reusing Design Strategies," Research in Engineering Design, Vol. 13, No. 2, 2002, pp. 109-121.

35. Oliver-Hoyo, M., and Beichner, R., "SCALE-UP: Bringing Inquiry-Guided Methods to Large Enrollment Courses," in Lee [24], pp. 51-69.

36. Hyman, M., and Luginbuhl, G., "Inquiry-Guided Learning and the Undergraduate Major in the Department of Microbiology," in Lee [24], pp. 129-141.

37. Kirkman, A.G., Byrd, M.V., Jameel, H., and Heitman, J.A., "The Challenge of Implementing an Inquiry-Guided Approach in a Highly Technical Curriculum," in Lee [24], pp. 143-156.

38. Rohrbach, R.P., Spurlin, J.E., Mayberry, K., and Rajala, S.A., "Engineering Computing as an Essential Component of Inquiry-Guided Learning," in Lee [24], pp. 157-171.

39. Haury, D., "Teaching Science through Inquiry," ERIC/CSMEE Digest, ED359048, 1993.

40. Shymansky, J., Hedges, L., and Woodworth, G., "A Reassessment of the Effects of Inquiry-Based Science Curricula of the 60's on Student Performance," J. Research in Science Teaching, Vol. 27, No. 2, 1990, pp. 127-144.

41. Rubin, S., Evaluation and Meta-Analysis of Selected Research Related to the Laboratory Component of Beginning College Level Science, Ph.D. dissertation, Temple University, 1996.

42. Colburn, A., "What Teacher Educators Need to Know about Inquiry-Based Instruction," $<$ http://www.csulb.edu/ acolburn/AETS.htm>. 
43. Barrows, H.S., and Tamblyn, R., Problem-Based Learning: An Approach to Medical Education, New York: Springer, 1980.

44. Boud, D., and Feletti, G., The Challenge of Problem-Based Learning, $2^{\text {nd }}$ ed., London: Kogan Page, 1997.

45. Dahlgren, M.A., "PBL through the Looking-Glass: Comparing Applications in Computer Engineering, Psychology and Physiotherapy," Intl. J. Engr. Education, Vol. 19, No. 5, 2003, pp. 672681.

46. Norman, G.R., and Schmidt, H.G., "The Psychological Basis of Problem-Based Learning: A Review of the Evidence," Academic Medicine, Vol. 67, No. 9, 1992, pp. 557-565.

47. Weiss, R., "Designing Problems to Promote Higher-Order Thinking," in D.S. Knowlton and D.C. Sharp, eds., Problem-Based Learning in the Information Age, New Directions for Teaching and Learning, \#95, San Francisco: Jossey Bass, Fall 2003, pp. 25-30.

48. Tan, O.S., Problem-Based Learning Innovation, Singapore: Thomson, 2003.

49. Duch, B.J., Groh, S.E., and Allen, D.E., The Power of Problem-Based Learning, Sterling, VA: Stylus, 2001.

50. Duch, B.J., "Models for Problem-Based Instruction in Undergraduate Courses," in Duch et al. [49], Ch. 4.

51. Woods, D.R., Problem-Based Learning: How to Gain the Most from PBL, Waterdown, ON: Donald R. Woods, 1994.

52. Acar, B.S., and Newman, I.A., "Students as Tutors-Learning Problem-Solving Skills by Tutoring PBL," Intl. J. Engr. Education, Vol. 19, No. 5, 2003, pp. 712-716.

53. Savin-Baden, M., and Major, C.H., Foundations of Problem-Based Learning, Maidenhead, Berks., England: Open University Press, 2004.

54. Tan, O.S., Little, P., Hee, S.Y., and Conway, J., eds., Problem-Based Learning: Educational Innovation across Disciplines, Singapore: Temasek Centre for Problem-Based Learning, 2000.

55. Woods, D., A. Hrymak, R. Marshall, P. Wood, C. Crowe, T. Hoffman, J. Wright, P. Taylor., K. Woodhouse and C. Kyle Bouchard, "Developing Problem-Solving Skills: The McMaster ProblemSolving Program," J. Engr. Education, Vol. 86, No. 2, 1997, pp. 75-91.

56. Hoyt, B., M. Hanyak, M. Vigeant, W. Snyder, M. Aburdene, D. Hyde, E. Mastascusa and M. Prince., "Project Catalyst: Introducing Systemic Change in Engineering Education," Proceedings, $31^{s t}$ ASEE/IEEE Frontiers in Education Conference, Reno, NV, October 2001.

57. Prince, M., M. Aburdene, B. Hoyt, D. Hyde, E. J. Mastascusa, L. Pease. W. Snyder and M. Vigeant, "Project Catalyst: Successes and Frustrations of Introducing Systemic Change to Engineering Education,” Proceedings, ASEE Annual Meeting, Albuquerque, NM, June 2001.

58. Jiménez, L., Font, J., and Farriol, X., "Unit Operations Laboratory Using Ill-Posed Problems,” Intl. J. Engr. Education, Vol. 19, No. 5, 2003, pp. 717-720.

59. Hadgraft, R., "Student Reactions to a Problem-Based Fourth-Year Computing Elective in Civil Engineering," Eur. J. Engr. Education, Vol. 22, No. 2, 1997, pp. 115-123.

60. Hadgraft, R., "Problem-Based Learning: Making It Work," in J.M. Simmons, D.F. Radcliffe, and K.B. Wallace, eds., New Opportunities and Challenges for Engineering Education, $4^{\text {th }}$ Annual Conference of the Australasian Association for Engineering Education, University of Queensland, 1992, pp. 134-139.

61. Hadgraft, R., "Experiences of Two Problem-Oriented Courses in Civil Engineering," in J.B. Agnew and C. Cresswell, eds., Broadening Horizons in Engineering Education, $3^{\text {rd }}$ Annual Conference of the Australasian Association for Engineering Education, University of Adelaide, 1991, pp. 292-297. 
62. Polanco, R., Calderón, P., and Delgado, F., "Effects of a Problem-Based Learning Program on Engineering Students' Academic Achievements in a Mexican University," Innovations in Education and Teaching International, Vol. 41, No. 2, 2004, pp. 145-155.

63. Nelson, W.A., "Problem-Solving through Design," in D.S. Knowlton and D.C. Sharp, eds., ProblemBased Learning in the Information Age, New Directions for Teaching and Learning, \#95, San Francisco: Jossey Bass, Fall 2003, pp. 39-44.

64. Dochy, F., Segers, M., Van den Bossche, P., and Gijbels, D., "Effects of Problem-Based Learning: A Meta-Analysis," Learning and Instruction, Vol. 13, 2003, pp. 533-568.

65. Gijbels, D., Dochy, F., P. Van den Bossche, P., Segers, M., "Effects of Problem-Based Learning: A Meta-Analysis from the Angle of Assessment," Review of Educational Research, Vol. 75, No. 1, 2005, pp. 27-61.

66. Vernon, D.T.A., and Blake, R.L., "Does Problem-Based Learning Work? A Meta-Analysis of Evaluative Research,” Academic Medicine, Vol. 68, 1993, pp. 550-563.

67. Dods, R.F., "An Action Research Study of the Effectiveness of Problem-Based Learning in Promoting the Acquisition and Retention of Knowledge," J. for the Education of the Gifted, Vol. 20, 1997, pp. 423-437.

68. Chung, J.C.C., and Chow, S.M.K., "Promoting Student Learning through a Student-Centered Problem-Based Learning Subject Curriculum," Innovation in Education and Teaching International, Vol. 41, No. 2, 2004, pp. 157-168.

69. Sharp, D.M.M., and Primrose, C.S., "The 'Virtual Family': An Evaluation of an Innovative Approach Using Problem-Based Learning to Integrate Curriculum Themes in a Nursing Undergraduate Programme," Nurse Education Today, Vol. 23, 2003, pp. 219-225.

70. Lieux, E.M., "A Comparative Study of Learning in Lecture vs. Problem-Based Format," About Teaching, \#50, Center for the Effectiveness of Teaching and Learning, University of Delaware, Spring 1996.

71. Blumberg, B., "Evaluating the Evidence that Problem-Based Learners are Self-Directed Learners: A Review of the Literature," in D.H. Evensen and C.E. Hmelo, eds., Problem-Based Learning: A Research Perspective on Learning Interactions, Mahwah, NJ: Erlbaum, 2000, pp. 199-226.

72. Coles, C.R., "Differences between Conventional and Problem-Based Curricula in Their Students' Approaches to Studying," Medical Education, Vol. 19, 1985, pp. 308-309.

73. de Graaff, E., and Kolmos, A., "Characteristics of Problem-Based Learning," Intl. J. Engr. Education, Vol. 19, No. 5, 2003, pp. 657-662.

74. Perrenet, J.C., Bouhuijs, P.A.J., and Smits, J.G.M.M., "The Suitability of Problem-Based Learning for Engineering Education: Theory and Practice," Teaching in Higher Education, Vol. 5, No. 3, 2000, pp. $345-358$.

75. Tan, O.S., Parsons, R.D., Hinson, S.L., and Sardo-Brown, D., Educational Psychology: A Practitioner-Researcher Approach (An Asian Edition), Singapore: Thomson, 2003.

76. Hung, W., Bailey, J.H., and Jonassen, D.H., "Exploring the Tensions of Problem-Based Learning: Insights from Research," in D.S. Knowlton and D.C. Sharp, eds., Problem-Based Learning in the Information Age, New Directions for Teaching and Learning, \#95, San Francisco: Jossey Bass, Fall 2003, pp. 13-23.

77. Caplow, J.H., Donaldson, J.F., Kardash, C.A., and Hosokawa, M., "Learning in a Problem-Based Medical Curriculum: Students' Conceptions," Medical Education, Vol. 31, 1997, pp. 1-8.

78. Huvard, G., J. Bara, N. Cain, B. Crosby, J. McLees, and G. Wnek, "ChemEngine: Realizing Entrepreneurship in Undergraduate Engineering Education," Proceedings, ASEE Annual Conference, American Society for Engineering Education, June 2001. More information about ChemEngine may be obtained from Dr. Gary Huvard, gary@huvard.com. 
79. Pavelich, M., B. Olds and R. Miller, "Real-World Problem Solving in Freshman and Sophomore Engineering," New Directions for Teaching and Learning, Vol. 61, 1995, pp. 45-54.

80. Rosenbaum, D.B., "Schools Erase Chalk-and-Talk," Engineering News-Record, 9/2/1996, pp. 24-30.

81. Heitmann, G., "Project-Oriented Study and Project-Organized Curricula: A Brief Review of Intentions and Solutions," Eur. J. Engr. Education, Vol. 21, No. 2, 1996, p. 121.

82. Mills, J.E., and Treagust, D.F., "Engineering Education-Is Problem-Based or Project-Based Learning the Answer?" Australasian J. Engr. Education, 2003-2004, $<h t t p: / / w w w . a a e e . c o m . a u / j o u r n a l / 2003 /$ mills_treagust03.pdf $>$.

83. Wessel, D., "Building a Better Engineer," Wall Street Journal, December 20, 2005, p. B1

84. Kolmos, A., Personal Communication, 2005.

85. Jensen, L.P., Helbo, J., Knudsen, M., and Rokkjǽr, O., "Project-Organized Problem-Based Learning in Distance Education," Intl. J. Engr. Education, Vol. 19, No. 5, 2003, pp. 696-700.

86. Galand, B., and Frenay, M., L'approche par Problèmes et par Projets dans l'Enseignement Supérieur: Impact, Enjeux et Defies, Louvain-la-Neuve: Presses Universitaires de Louvain, 2005. A video of Professor Frenay presenting (in English) a description of the Louvain curriculum and summarizing the assessment and evaluation of its effectiveness can be viewed at $<$ http://video.aau.dk/lectures/I20/I20_UCPBL.html>.

87. Thomas, J.W., A Review of Research on Project-Based Learning, San Rafael, CA: Autodesk Foundation, 2000.

88. Kardos, G., and Smith, C.O., "On Writing Engineering Cases," Proceedings of ASEE National Conference on Engineering Case Studies, March 1979, $<$ http://www.civeng.carleton.ca/ECL/cwrtng.html $>$.

89. Lundeberg, M., Levin, B., and Harrington, H., Who Learns What from Cases and How? The Research Base for Teaching and Learning with Cases, Mahwah, NJ: Lawrence Erlbaum Associates, Inc., 1999.

90. Lynn, Jr., L.E., Teaching and Learning with Cases, New York: Chatham House Publishers, 1999.

91. Kardos, G., "Engineering Cases in the Classroom," Proceedings of ASEE National Conference on Engineering Case Studies, March 1979, <http://www.civeng.carleton.ca/ECL/cclas.html>.

92. Lohman, M., "Cultivating Problem-Solving Skills through Problem-Based Approaches to Professional Development," Human Resource Development Quarterly, Vol. 13, No. 3, 2002, p. 243.

93. Herreid, C.F., "What is a Case?” J. Coll. Science Teaching, Vol. 27, No. 2, 1997, pp. 92-94.

94. Fitzgeard, N., "Teaching with Cases," ASEE Prism, 4(7), 16-20 (1995).

95. Ricards, L.G., Gorman, M. Scherer, W.T., and Landel, R.D., "Promoting Active Learning with Cases and Instructional Modules," J. Engr. Education, Vol. 84, No. 4, 1995, pp. 375-381.

96. Mayer, R., "Invited Reaction: Cultivating Problem-Solving Skills through Problem-Based Approaches to Professional Development," Human Resources Development Quarterly, Vol. 13, No. 3, 2002, p. 263.

97. Fasko, D., "Case Studies and Method in Teaching and Learning," presented at the Annual Meeting of the Society of Educators and Scholars, Louisville, KY, April 2003.

98. Adams, M.E., The Response to Eleventh Graders to the Use of the Case Method of Instruction in Social Studies, Unpublished master's thesis, Simon Fraser University, Bambry, B.C. (Cited in Ciardiello, A., "A case for case-based instruction" in C.N. Hedley, P. Antonacci, and M. Rabinowitz, eds., Thinking and literacy: The mind at work, Hillsdale NJ: Erlbaum, 1995.)

99. Levin, B., "The Influence of Context in Case-Based Teaching: Personal Dilemmas, Moral Issues or Real Change in Teachers' Thinking?" Paper presented at the annual meeting of the American Educational Research Association, Chicago, April 1997. (Cited by Lundeberg et al. [89].)

100. Gabel, C., "Using Case Studies to Teach Science," presented at the Annual Meeting of the National Association for Research in Science Teaching, Boston, MA, March 28-31, 1999. 
101. Katsikitis, M., Hay, P.J., Barrett, R.J., and Wade, T., "Problem- Versus Case-based Approaches in Teaching Medical Students about Eating Disorders: A Controlled Comparison," Ed. Psychology, Vol. 22, No. 3, 2002, pp. 277-283.

102. Spencer, J.A., and Jordan, R.K., "Learner-Centred Approaches in Medical Education," BMJ (British Medical Journal), Vol. 313, 1996, pp. 275-283.

103. Leonard, W., "An Experimental Test of an Extended Discretion Laboratory Approach for University General Biology," J. Research in Science Teaching, Vol. 26, No. 1, 1988, pp 79-91.

104. Holcomb, C., "The Effect of Degrees of Direction in the Qualitative Analysis Laboratory on Retention of Learning," J. Research in Science Teaching, Vol. 8, No. 2, 1971, pp. 165-169.

105. Kersh, B., "Motivating Effect of Learning by Directed Discovery," J. Ed. Psychology, Vol. 53, 1962, pp. $65-71$.

106. Kittell, J., "An Experimental Study of the Effects of External Direction during Learning on Transfer and Retention of Principles," J. Ed. Psychology, Vol. 48, 1957, pp. 391-405.

107. Wittrock, M.C., "Verbal Stimuli in Concept Formation: Learning by Discovery," J. Educational Psychology, Vol. 54, 1963, pp. 183-190.

108. Westbrook, S., and Rogers, L., "Examining the Development of Scientific Reasoning in Ninth-Grade Physical Science Students," J. Research in Science Teaching, Vol. 31, No. 1, 1994, pp. 65-76.

109. Singer, R. and Pease, D., "Effect of Guided vs. Discovery Learning Strategies on Initial Motor Task Learning, Transfer and Retention," The Research Quarterly, Vol. 49, No. 2, 1978, p. 206.

110. Just-in-Time Teaching Web site, <http://webphysics.iupui.edu/jitt/jitt.html>.

111. Modesitt, K.L., Maxim, B., and Akingbehin, K., "Just-in-Time Learning in Software Engineering," $J$. Computers in Mathematics and Science Teaching, Vol. 18, No. 3, 1999, pp. 287-301.

112. Novak, G.M., Patterson, E.T., Gavrin, A.D., and Christian, W., Just-in-Time Teaching: Blending Active Learning with Web Technology, Upper Saddle River, N.J.: Prentice-Hall, 1999.

113. Rozycki, W., "Just-in-Time Teaching," <http://www.indiana.edu/ rcapub/v22n1/p08.html>.

114. Hake, R., "Interactive-Engagement vs. Traditional Methods: A Six-Thousand-Student Survey of Mechanics Test Data for Introductory Physics Courses," Am. J. Physics, Vol. 64, No. 1, 1998, p. 66.

115. Mager, R.F., Preparing Instructional Objectives, $3^{\text {rd }}$ ed., Atlanta, GA: Center for Effective Performance, 1997.

116. Gronlund, N.E., How to Write and Use Instructional Objectives, $6^{\text {th }}$ ed., Upper Saddle River, NJ: Prentice-Hall, 2000.

117. Felder, R.M., and Brent, R., "Designing and Teaching Courses to Satisfy the ABET Engineering Criteria," J. Engr. Education, Vol. 92, No. 1, 2003, pp. 7-25, <http://www.ncsu.edu/felderpublic/Papers/ABET_Paper_(JEE).pdfs.

118. Smith, K.A., Sheppard, S.D., Johnson, D.W., and Johnson, R.T., "Pedagogies of Engagement: Classroom-Based Practices," J. Engr. Education, Vol. 94, No. 1, 2005, pp. 87-101.

119. Felder, R.M., and Brent, R., "Navigating The Bumpy Road to Student-Centered Instruction," College Teaching, Vol. 44, No. 2, 1996, pp. 43-47, <http://www.ncsu.edu/felder-public/Papers/Resist.html >. 


\section{AUTHOR'S BIOGRAPHIES}

Michael Prince is a professor in the Department of Chemical Engineering at Bucknell University, where he has been since receiving his Ph.D. from the University of California at Berkeley in 1989. He is the author of several education-related papers for engineering faculty and gives faculty development workshops on active learning. He is currently continuing the work of Project Catalyst, an NSF-funded initiative to help faculty re-envision their role in the learning process, and researching the use of inductive teaching methods to correct common student misconceptions in engineering. Address: Department of Chemical Engineering, Bucknell University, Lewisburg, PA 17837; telephone: 570-577-1781; e-mail: prince@bucknell.edu.

Richard M. Felder is Hoechst Celanese Professor Emeritus of Chemical Engineering at North Carolina State University. He received his BChE from City College of New York and his PhD from Princeton University. He is coauthor of the text Elementary Principles of Chemical Processes (Wiley, 2005) and co-director of the ASEE National Effective Teaching Institute. Address: Department of Chemical Engineering, N.C. State University, Raleigh, NC 276957905; e-mail: rmfelder@mindspring.com. 